\title{
バラエティ番組を用いた日本語授業の振り返り 一香港の初級後半・中級の社会人学習者を対象にした実践から一 A reflection on teaching Japanese through variety show — For adult beginner/intermediate learners in Hong Kong —
}

\section{李 咏茵/梁 嘉欣 香港理工大学大学院生}

\section{要旨}

本稿は、社会人の日本語学習者を対象に日本語の会話能力を高めることを目的と して実施した、日本のバラエティ番組を用いた日本語授業の報告である。実施した 授業を振り返るため、学習者からのフィードバックと教師自身の内省から、バラエティ 番組を用いた授業の実用性を検証する。

キーワード :

日本語教育実践、実践研究、省察、振り返り、バラエティ番組を用いた授業 


\section{バラエティ番組を用いた日本語授業の実践及び振り返り 香港の初級後半・中級の社会人学習者を対象にした実践から一}

\section{李 咏茵/梁 嘉欣 香港理工大学大学院生}

\section{1.はじめに}

国際交流基金 (2013) が 2012 年に行った「日本語教育機関調査」では、世界の 55.5\% の学習者が「日本語でのコミュニケーション」を目的に日本語を学んでいるという。 だが、従来の海外の学習者に向けた会話教材の多くは文法を重視し、場面別にカテゴ リー化されたものが多く、日本語学習者でもある筆者達はその日常生活での実用性に 疑問を持ち、授業の楽しさにも欠けていると感じていた。また、同調査では、香港の 日本語学習者は学校教育以外の機関で日本語を学習する者の数が全体の 7.5 割を占 めているとしている。そして、その多くの学校教育以外の教育機関の授業では、広東 語や英語など学習者の母語や第 2 言語を用いて行われることが多く、学習者は普段か ら日本語に触れる機会も少ないと考えられ、会話能力が伸びにくいということも筆者 自身の経験から考えられる。そこで、筆者達は学習者が日常的に日本語を聞ける・話 せるようになるため、授業にバラエティ番組を生教材として導入することにした。本 稿では、香港の社会人学習者に向けて行った実践を振り返り、バラエティ番組の授業 への活用の意義について検討する。

\section{2. 授業実践に向けての準備}

\section{1 授業の目的}

筆者達は二人とも香港の日系企業に勤務し、それぞれ採用面接を行う面接官として の長年の経験がある。面接に来る日本語学習者及び採用者を観察していく中で、香港 の学習者の多くは日本語能力試験 1 級・2 級に合格し、中級・上級と判断される能力を 持っていても、メールや報告書など一定の規則のある書類は十分に作成できるが、実 際に日本語でコミュニケーションをしたりすることができないということを常日頃か ら感じていた。また、面接では学校で教わった決まりの回答が多いことから、学校の 会話教材には実用性が久けているのではないかと疑問に感じていた。そして、筆者が 接する同僚達に日本語で勉強したいことは何かと尋ねると、ほぼ全員が会話能力の向 上であると答えた。そこで、同僚達の日本語会話能力を高めることを目的に、授業実 践を行うことにした。そこでは、前述した通り、通常の教科書では退屈になりやすい ため、楽しく日本語を学べるようにと、日本のバラエティ番組を授業に取り入れるこ とにした。 


\section{2 対象とする学習者のレディネスチェック}

授業を行う前にはアンケートとインタビューを通してレディネスチェックを行った。 今回集まった学習者は 7 人で、年需は 20 代から 30 代であり、全員筆者達と同じ日系 企業で働いている人達であった。参加者の多くは、日本人の顧客と日本語でやり取り することが多いため、よりよい関係を築くためには、日本語の日常会話の能力を高め たいと考えているようであった。すでに述べた通り、会話が苦手というのは広東語を 母語とする日本語学習者の共通の欠点とも言われており、今回の学習者達も主に広東 語で日本語の授業を受けていた。学習者は日本語能力試験 N3 から N1 ${ }^{1}$ のいずれかに 合格しており、日本語を 3 年から 23 年勉強していた。いずれの学習者も会話能力に 学習の困難さを感じていていた。

23 年間日本語を勉強した学習者は香港人と日本人のハーフで、母親が日本語教師を しているということで、彼に授業の全体を見てもらい、授業を評価してもらった。 第三者に授業を評価してもらうことでより客観的で、建設的な授業の改善・向上が 期待できると考えた。

\section{3 教材デザイン}

中山（2008、2012）と吉村（2010）は映画を用いて日本語授業を実践することは、 映像教材としての価值を肯定し、文化的交流と異文化理解にも効果的であるとして いる。なお、香港でバラエティ番組を用いた授業を報告している趙・鄥・滕(2014)も 日本のテレビ番組やドラマは日本語教育で貴重なリソースであると指摘している。 だが、ドラマや映画はストーリーや人物の関係性を理解しておかなければ教材として 使用しにくいと考えられ、本実践では内容を取りきりやすいバラエティ番組を使う ことにした。授業で用いるバラエティ番組の候補として、「クイズ! それマジ! ? ニッポン（以下、それマジ）」、「ザ！世界仰天ニュース（以下、仰天ニュース）」、 「痛快 TV スカッとジャパン（以下、スカッとジャパン）」、「ニンゲン観察バラエティ 『モニタリング』（以下、『モニタリング』）」を考えた。

「それマジ」は、番組で使用される日本語は日常的に見られるものも多く、教材と しては利用できると感じられたが、番組内ですでに詳しく解説が行われているため、 教材というよりも学習者への参考資料として勧めることにした。「仰天ニュース」と 「スカッとジャパン」はショートドラマから構成される番組で、短い動画は授業の時間

\footnotetext{
12010 年（平成 22 年）の改定で、従来の 1 級から 4 級の資格が N1 から N5 の 5 段階になった。
} 


\section{バラエティ番組を用いた日本語授業の実践及び振り返り \\ 一香港の初級後半 · 中級の社会人学習者を対象にした実践から一}

内で効果的に使用することができる。だが、「仰天ニュース」はドキュメンタリーや 事件の内容が多く、内容は深刻で、日本語も難しいと考え、本実践の対象者である 中級レベルには採用しなかった。そして、「スカッとジャパン」はクレームに使用 する表現などが多く、演技が不自然に誇張的で、日本語の学習の教材として向いてい ないと判断し、採用しないことにした。したがって、日本の人々の日常生活を観察 する「モニタリング」を採用することにした。この番組は、日常の日本語を聞くこと ができ、またテーマも設定されているため、グループディスカッションにも向いて いると考えた。

なお、筆者達が香港で働く日本語教師を対象に行ったインタビューでは、会話の 授業では学習者の興味を引くことが難しいということも聞かれた。だが、 「モニタリング」は面白さもあり、学習者の興味を引きつけることができるのではない かと考えた。また、番組では字幕テロップが多数使用されており、難しい漢字や聞き 取れない箇所は字幕テロップで確認できる。

\section{4 授業内容・シラバス}

筆者の二人が最初に日本語を勉強した時、李は日本人教師から直接法で教わり、 梁は広東語・英語で教わった。筆者達の経験から、直接法のメリットとして会話能力 が伸びやすく、その一方で学習者が全部内容を理解することは難しいというデメリット があることを感じていた。そして、学習者の母語で教わった場合は、その逆であると 考えられる。本実践では筆者達二人が連携して授業を行ったため、基本的には日本語 で授業を行うが、詳しい説明や学習者が理解しないところには広東語でサポートする ことにした。また、少人数のクラスであったため、学習者一人ひとりに発表して もらったり、回答してもらったり、できるだけ日本語で話してもらうようにした。

本実践では、話題シラバスを取り入れた。「モニタリング」には様々な題材があり、 その中から話題を広げやすい「温泉」と「カップルのけんか」を選択した。また、 トップダウンモデルを利用し、学習者達に話題や背景を予想させ（前作業）、内容を 確認し（本作業）、最後に文法に関する説明を行った（後作業）。授業は約 2 時間 だった。 


\section{3. 授業実践と考察}

今回の授業実践は「モニタリング」に合わせ、教材をデザインし、授業を進めた。 本節では、教材について前作業・本作業・後作業に分けて詳しく説明する。

\section{1 前作業}

本実践でのテーマは「温泉」と「カップルのけんか」の二つである。学習者の興味 を引き、これから見る番組の内容を予測させるため、各テーマの前には「ウォームア ップ」を行った。

まず、「温泉」についての授業では、まずは学習者が話してもらうよう、「温泉は 入ったことがありますか」を聞き、何人の学習者が台湾や日本での体験談を話しても らった時、学習者は日本の「銭湯」と「温泉」の違いを分からないことが分かり、補 足情報として説明した。

次に、二つのテーマも「ウォームアップ練習」を準備した。「温泉」は入浴マナー のマッチング練習（図 1 を参照）で、「カップルのけんか」では番組の冒頭に出て くることわざの意味（図 2 を参照）を考えさせ、そして意味を教えた。マッチング 練習では学習者たちがお互いに話し合いしながら正解を導いたが、ことわざは普段 あまり使われない言葉で、答えを導き出すため、「彼はとても機嫌が悪いから、話し かけない方がいいよ。触らぬ神に崇りなしというからね。」などの具体例を用いて 説明を試みたが、難しいという学習者の声があったため、最後は広東語でも解説した。

\section{図 1：「温泉」のウォームアップ練習}

A. 下記のイラストを見て、どのマナーを表していますか。

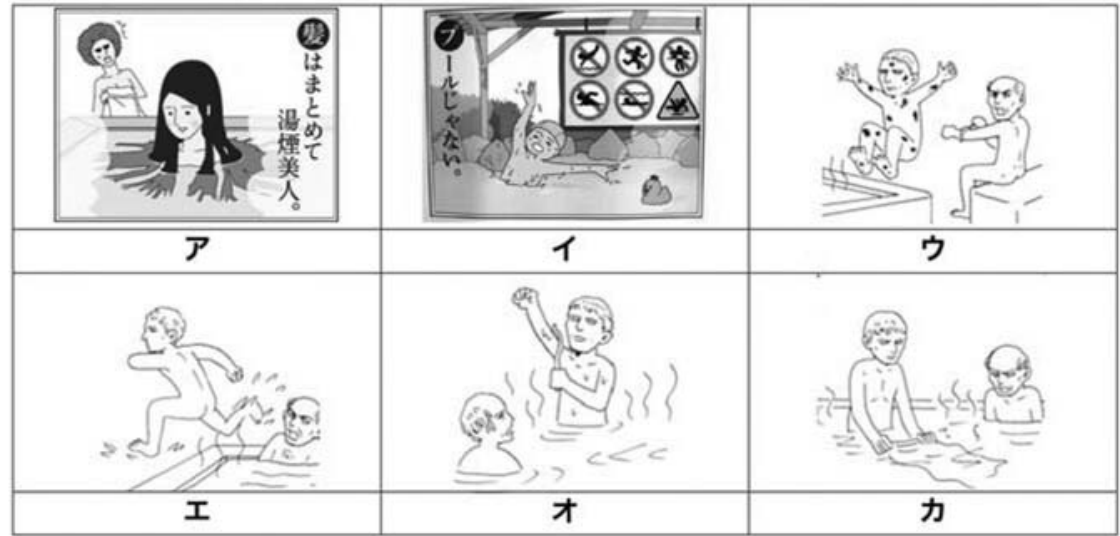




\section{図 2 : 「カップルのけんか」のウォームアップ練習}

$\nabla$ ウォームアップ
A. この二つのことわさの意味を考えてみてください。
1）触らぬ神に崇りなし

2）夫婦喧㗆は犬も食わない

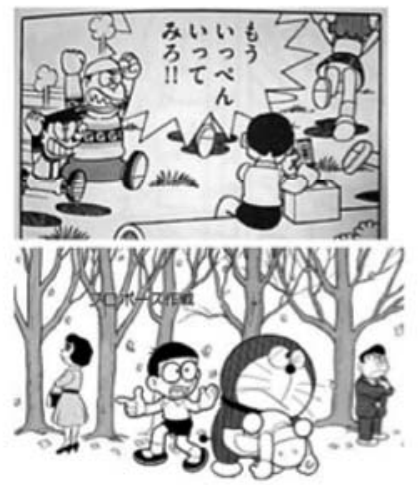

次に、教師から学習者に質問をすることで、簡単な会話を行った。だが、観察した ところ、学習者達は書く練習に対しては集中しているものの、会話の練習には少々 苦手意識を持ち、日本語で話すことを恥ずかしいように感じているようで、積極的に は話さなかった。

\section{2 本作業}

「ウォームアップ」の後、学習者に『モニタリング』を見せた。本実践で用意した 2 本の動画はそれぞれ 10 分前後である。学習者がきちんと内容を理解したかを確認す るため、書く練習（図 3 を参照）を行い、質問になるべく日本語で答えてもらうよう にした。

図 3：番組内容に合わせて作った書く練習

B. ビデオを見て、下記の単語を確慧しましょう。

\begin{tabular}{|lllllll|}
\hline しきたり & モニター調査 & 仕掛け & 戸惑い & ざわつき & 点呼 & スルー \\
& & & & & \\
& 切ない & 洗い場 & 不信感 & 不機嫌 & & \\
\hline
\end{tabular}

C. 下記の類似吾はB.のどの言葉に当てはまりますか。答えを_—に書いて下さい。

習慣

困惑

見て見ぬふり

企み

心苦しい

賑やか

C.まずは関東編のビデオを見て、どんな文句・不満を言ったのか、またその文句・不 満にどのようなアドバイスがあったのを聞き取り、メモしてください。

\begin{tabular}{|l|l|l|}
\hline & どんなことについて文句を言ったのか & どういうアドバイスがあった \\
\hline \multirow{3}{*}{1} & & \\
& & \\
\hline
\end{tabular}


また、自分の経験と意見を述べられる力を身につけて欲しいと考えたため、番組に 関するいくつかの話題をグループで話させたり、発表させたりした。だが、グループ 内では広東語と日本語の両方を使って話し合っていたが、発表では、教師から促して も自発的には話してはくれなかった。日本語で話すことに対して苦手意識を持ってい たため、教師達が広東語の媒介語を使い誘導をすると、少しではあるが、話してくれ た。なお、漢字の単語はある程度推測できたが、平仮名の単語、特に「スルー」の ような和製英語は少し難しいものもあるようで、答え合わせの時に一つ一つ説明した。

\section{3 後作業}

番組を見終わり、話題について話し合ってからは、学習者が単語・文法・表現に ついてきちんと理解できるように、後作業では文法などを詳しく説明することにした。 「温泉」の授業では、決まりについてはウォームアップで説明していたため、後作業で は温泉についての文章を使って、擬態語を紹介した（図 4 を参照）。擬態語はテレビ やアニメでもよく使用される表現で、学習者達の興味を引き付けることができた。 参考した教材はイラストもあるため、学習者はイラストと内容を読みながら話し合い、 答えを割り出すことも見られた。

\section{図 4：擬態語のマーチング練習及び解説}

\section{（参考教科書：絵で分かる日本語使い分け辞典 1000 P. 45, 48)}

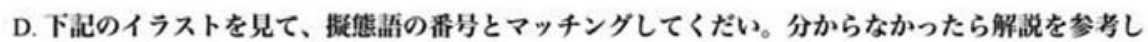
てください。
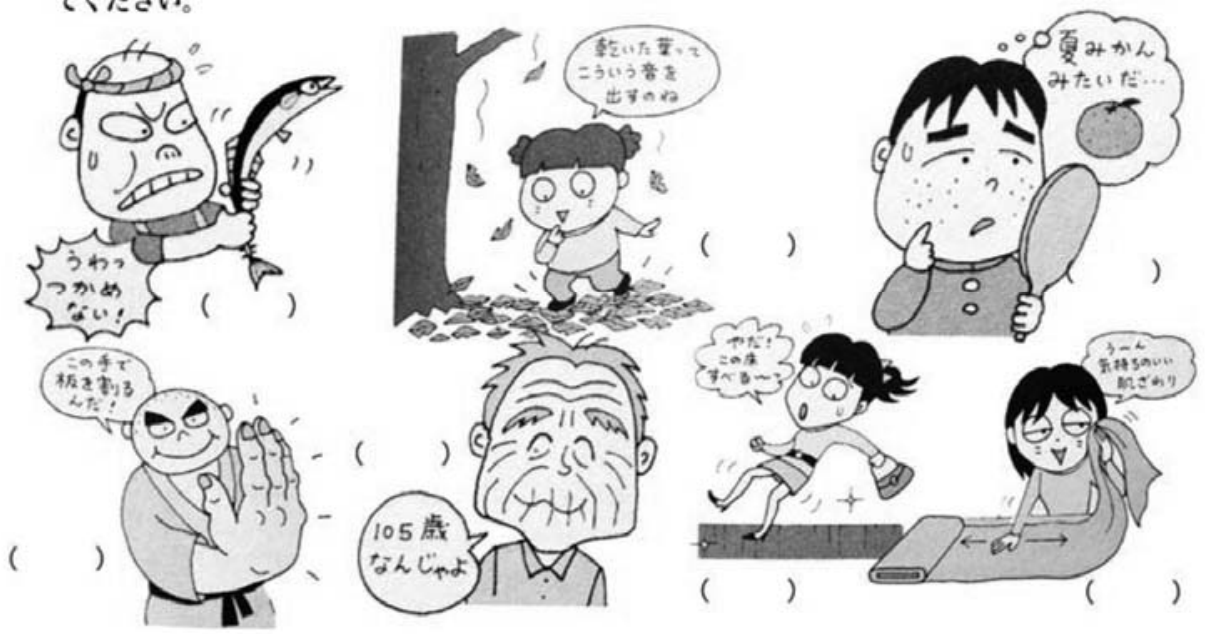
続いて「カップルのけんか」では番組の中に出てきた言葉を書き起こし、学習者に どの表現なのかを考えてもらい（図 5 を参照）、最後に各表現について詳しく説明し た（図 6 を参照）。会話力を高めることが目的であったため、表現は話し言葉のみ 紹介した。また、会話においてイントネーションによって、気持ちの表現が違うため、 教師が説明の時にもわざとイントネーションを強調し説明を行った。

\section{図 5:表現を考える活動}

（参考資料：聞いて覚える話し方 日本語生中継 中〜上級編）

D.もう一度ビデオを見て、イントネーションを注意していながら、下記の表現を顧認 してみましょう。下記のフレーズはどの表現ですか。
ア）文句を言う
イ）言い訳する
ウ) 行為を要求する
工) 提案

1 言ってほしいタイミングに言ってくれたことないじゃん

2 不安なんだもん（）

3 彼女が「言ってほしい」って言ってるんだったら、言った方がいいと思います ( )

4 断ればいいじゃん、行かなくても良くない?

5 私だったら断るけどね!

6 付き合いとかもあるでしょ?

7 バレる嘘はつかないほうがいいと思います。つくなら突き通した方がいいと思い ます。

\section{4. 評価と省察}

本実践を振り返り、授業を客観的に評価するため、学習者、学習者と教師以外の 第三者、教師の 3 つの視点から授業を評価することにした。以下、詳しく説明したい と思う。

\section{1 学習者からの評価}

授業が終わった後、学習者に評価シートを記入してもらった。表 1 に評価シートの 構成と質問項目を挙げる。 
表 $1:$ 学習者による評価シートの構成と質問項目

\begin{tabular}{|c|c|c|l|}
\hline 構成 & 質問数 & 回答方法 & \multicolumn{1}{c|}{ 質問内容 } \\
\hline $\begin{array}{l}\text { A. 授業全般に } \\
\text { ついて }\end{array}$ & 10 & 選択式 & $\begin{array}{l}\text { (1) 番組・ビデオについて } \\
\text { (2) バラエティ番組を用いた教え方 } \\
\text { (3) 練習の内容・学習量 } \\
\text { (4) 教師の話すスピートや言葉遣い }\end{array}$ \\
\hline $\begin{array}{l}\text { B. 授業の内容 } \\
\text { について }\end{array}$ & 3 & 記述式 & $\begin{array}{l}\text { (1) 授業で良かった所 } \\
\text { (2) 授業で難しかった所 } \\
\text { (3) 授業で改善してほしい所 }\end{array}$ \\
\hline
\end{tabular}

「A．授業全般について」の質問は上記の通り、学習者に選択式で点数を付けて もらった。1から 5 点あり、1は「思わない」、5 は「強く思う」である。結果を 統計し、各質問の平均点数は 4 点以上で、全体的には満足していたと考えられる。

そして、「B．授業の内容について」の記述式質問は3つある。授業の良かったと ころについては、番組は面白く、会話部分は実用的で、擬態語が面白かったなどの 意見があった。それから、授業で難しかったところについては、番組の話すスピード が早すぎてうまく聞き取れなかったと、単語の説明は足りなかったので意味を十分に 理解できなかった、の 2 点があった。番組については字幕テロップがあったため、 内容を理解できたという意見もあった。本指摘を改善寸るため、今後は番組に日本語 の字幕を入れることを考えている。日本語の字幕を入れると、学習者が理解しや寸く なり、表現も確認できるだろう。

次に改善してほしいところについて、学習者のコメントは(1)使用言語、(2)番組に ついて、(3)教育スキルの三つにまとめられる。授業では主に日本語を使用し、単語・ 文法・言語表現なども日本語で説明した。それに対して、理解がしにくいため、もう 少し広東語・英語などの媒介語を入れたほうがいいという意見があった。また、こと わざや単語の説明では、日常で使える例文も紹介してほしいという声もあった。

続いて、番組を見終わった後、すべて理解できたとは判断できない学習者もいる ため、一度みんなで番組の内容を広東語で確認した方がいいという意見もあった。 最後に、学習者が授業の内容を本当に理解しているかどうか、次のセクションに入る 前にもう一度確認する必要があるという声もあった。そして、会話練習に設定した ディスカッションでは、初・中級の日本語レベル学習者には自由回答の質問を避けた ほうがいいという意見もあった。 


\section{バラエティ番組を用いた日本語授業の実践及び振り返り \\ 一香港の初級後半・中級の社会人学習者を対象にした実践から一}

\section{2 第 3 者からの評価}

前述のように、本実践を第三者である $\mathrm{S}$ さんに授業を見てもらい、評価してもらった。

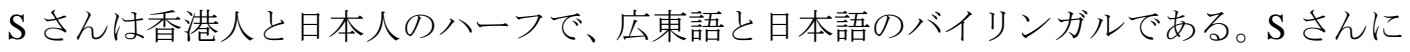
教材、授業と学習量の 3 方面から評価してもらった。

まずは教材について、今回の授業で教えた単語は初・中級レベルの日本語学習者に 少々難しすぎると思えたため、教える際にはまず広東語・英語で説明し、さらに例を 挙げて学習者の理解を深めたほうがいいというアドバイスを受けた。また、単語の 紹介はいいが、香港人の学習者は漢字から意味を推測・発音しがちであるため、漢字 に振り仮名を付けて読み方を教え、また、漢字よりカタカナの単語を教えたほうが 効果的であるとも指摘された。さらに、「カップルのけんか」の番組ではせっかく 関東と関西の比較があったので、学習者に東西の言葉や文化の違いについて例を挙げ、 詳しく説明したほうが面白いのではないかというコメントも受けた。なお、教材で 番組に出てきたことわざを紹介したが、やはり難しいと感じられ、代わりによく耳に する言葉を紹介したほうが効果的ではないかという指摘もあった。

次に授業について、授業のときに学習者が緊張していると感じ、特に会話練習の時、 学習者が緊張しているせいであまり話さないというコメントがあった。S さんはまず 番組について簡単な質問をし、学習者たちをリラックスさせてから会話の練習を始め るべきだと助言した。特に初級レベルの日本語の学習者に対し、内容が難しすぎると わからなくて挫折感を感じやすくなるため、教師はよく学習者を観察し、分からない と気づくと説明を入れて学習者に自信を付けさせることは大切だと教えてもらった。

最後は学習量について 2 時間の授業で 2 つのテーマも教えるのは内容が濃縮され、 内容が面白くても、学習者に無理やりたくさんの情報をインプットしてしまい、逆に 理解しきれないのではないかという指摘があった。確かに今回は会話しか考えていな かったので、より多く教える一心で学習者に対する配慮が足りなかった。

\section{3 教師の内省 · 改善}

岡崎（1997）は自分や他の教師のクラスでの教授・学習過程を理解するために、 教授過程を観察して振り返る中で教授・学習過程の重要な諸点を発見していく教師を 「内省的実践家」として位置付けた。教師は内省を通して、授業の改善やスキル向上を 期待できる。 
そこで、私達は「授業自己評価シート」を用いて自己評価を行った。表 2 に評価 シートの構成と質問項目を挙げる。

表 2 : 教師による自己評価シートの構成と質問項目

\begin{tabular}{|c|c|c|c|}
\hline 構成 & 質問数 & 回答方法 & 質問内容 \\
\hline $\begin{array}{l}\text { A. 授業の目標 } \\
\text { について }\end{array}$ & 2 & 記述式 & $\begin{array}{l}\text { (1) 今回の授業の目標 } \\
\text { (2) 学習者についてのこと・ } \\
\text { イメージ }\end{array}$ \\
\hline $\begin{array}{l}\text { B. 授業の目標の } \\
\text { 達成について }\end{array}$ & 4 & 記述式 & $\begin{array}{l}\text { (1) 学習者の分かった・ } \\
\text { 分からなかったこと } \\
\text { (2) 学習者が分かったきっかけ } \\
\text { (3) 学習者が分からなかった原因 }\end{array}$ \\
\hline $\begin{array}{l}\text { C. 学習者 } \\
\text { について }\end{array}$ & 4 & 記述式 & $\begin{array}{l}\text { (1) 学習者が興味と引いた・ } \\
\text { 引かなかったこと } \\
\text { (2) 学習者の参加率 } \\
\text { (3) 学習者に対するイメージの変化 } \\
\text { (4) クラスの雰囲気 }\end{array}$ \\
\hline $\begin{array}{l}\text { D. 教師自身 } \\
\text { について }\end{array}$ & 2 & 記述式 & $\begin{array}{l}\text { (1) どういう工夫がされたのか } \\
\text { (2) 授業の進み速さの適切性 }\end{array}$ \\
\hline $\begin{array}{l}\text { E. 授業の全体 } \\
\text { について }\end{array}$ & 3 & 記述式 & $\begin{array}{l}\text { (1) 参考になる学習者の意見 } \\
\text { (2) 授業改善のための方策 } \\
\text { (3) 全体的な自己評価 }\end{array}$ \\
\hline
\end{tabular}

まずは今回の授業では、学習者が主に媒介語を使用して日本語を勉強してきたため、 積極に話してくれるか、内容が難しすぎではないかなどの心配があった。内容の点は、 やはり単語の説明が足りなかったため、十分に理解してもらえなかった。また、こと わざは専門的なものであり、学習者のレベルに合っていないとの指摘があった。確か に指摘の通り、「カップルのけんか」の内容はやや設定が難しかった。同じクラスで もレベルの差があるため、教師が内容をデザインするときは全員を考慮し、バランス を取って教材を作らないといけないと改めて考えさせられた。また、Sさんからの アドバイスとして、自分の母親が教えているときは必ず単語を毎週繰り返して インプットするといい、一回だけの説明では完璧に理解することは難しいという。 


\section{バラエティ番組を用いた日本語授業の実践及び振り返り \\ 一香港の初級後半・中級の社会人学習者を対象にした実践から一}

次に、全体の授業を見渡し、学習者たちは予想通り積極的に話さなかった。しかし、 少し質問してみて、誘導してみたら徐々に話すようになった。今回、学習者が積極的 に話さなかった原因として、授業が教師主導になりがちであったためだと考えられる。 学習者達がなかなか自発的に話さないため、教師が一方的に質問する形になって しまった。今後の授業では、まずは学習者達がグループで話し合ってから発表して もらったほうがいいだろう。

そして、話すスピートについては学習者からは適切だと評価されたが、自分達の 観察では少々速かったように感じる。日本語レベルの低い学習者には少し難しかった ようで、何回か繰り返したり、広東語を入れたりして理解を促すことにした。なお、 「カップルのけんか」の番組では少し関西弁も入っていたので、「分からない」、「聞 き取れない」という意見もあった。また、「関西弁について勉強したい」という意見 や、関西弁と共通語の違いについての質問もあつた。授業で関西弁の紹介を少し取り 入れていれば、文化面の理解も会話への理解も深められたのではないかと考えられる。 また、「温泉」の授業はゆっくり説明できたことに対して、「カップルのけんか」は 少し速かった。振り返ってみると、学習者達はきちんと全ての文法や表現を理解でき るのか疑問を持っている。そのため、「温泉」の授業に単語・文法・ロールプレイ などを取り入れるなど内容を少し増やしていれば、充実した授業になったのではない だろうか。

\section{5. 終わりに}

本実践を通じて、バラエティ番組の実用性を検証してみた結果、学習者の興味を 引き付けることは確実であり、学習者達は授業にも集中していた。だが、今回選択 した内容は関西弁なども入っており、学習者には予想外の内容だったと思われる。 実際には日常で使用する会話を勉強させたかったが、番組の選択や使える内容を整理 するのにかなりの時間と手間がかかり、教師にとっては負担になってしまう。今後の 課題として、より簡単に作れる映像教材としてバラエティ番組以外の物を調査する 必要があると考えている。例えば、日本人に実演してもらったり、実際の映像教材に 工夫を入れたりするなどである。今後は、本実践に参加した学習者のフィードバック と自分たちの考察を参考にし、学習者側にも配慮をし、よりよい教材をデザインし、 授業できたらと考えている。 


\section{参考文献}

岡崎敏雄・岡崎 (1997)『日本語教育の実習：理論と実践』アルク

国際交流基金 (2013)『2012 年度 日本語教育機関調査 結果概要＼cjkstart抜粋』 くろしお出版

国際交流基金 (2012)『2012 年度日本語教育機関調査結果』

$<\underline{\text { http://www.jpf.go.jp/j/project/japanese/survey/area/country/2014/hongkong.html\#KEKKA }>}$

(2015 年 4 月 26 日参照)

中山英治 (2008) 「授業閒の連携を活用したタイの大学における新しい試み一授業の実践報告と映画

『男はつらいよ』の教材価値一」『アジアにおける日本語教育一「外国語としての日本語」修士課

程設立一周年セミナー論文集一』チュラーロンコーン大学文学部, pp.49-72

中山英治 (2012) 「日本語教育における映画の一般的な教材価值と社会参画を支援できる教材価值一

『男はつらいよ』を資料として一」『特集緒言 特集：教室中心主義からの解放』早稲田大学日本語

教育研究センター, pp. 119-137

吉村弓子(2010)「映画を用いた日本語教育」『北海道言語文化研究』8, 北海道言語研究会、pp.3-12 趙晨・鄥䑣・滕安麗(2014)「生教材を活用したタスクベースの会話教材の開発」『日本学刊』

17, pp.133-149

\section{付録資料 1 ：教科書}

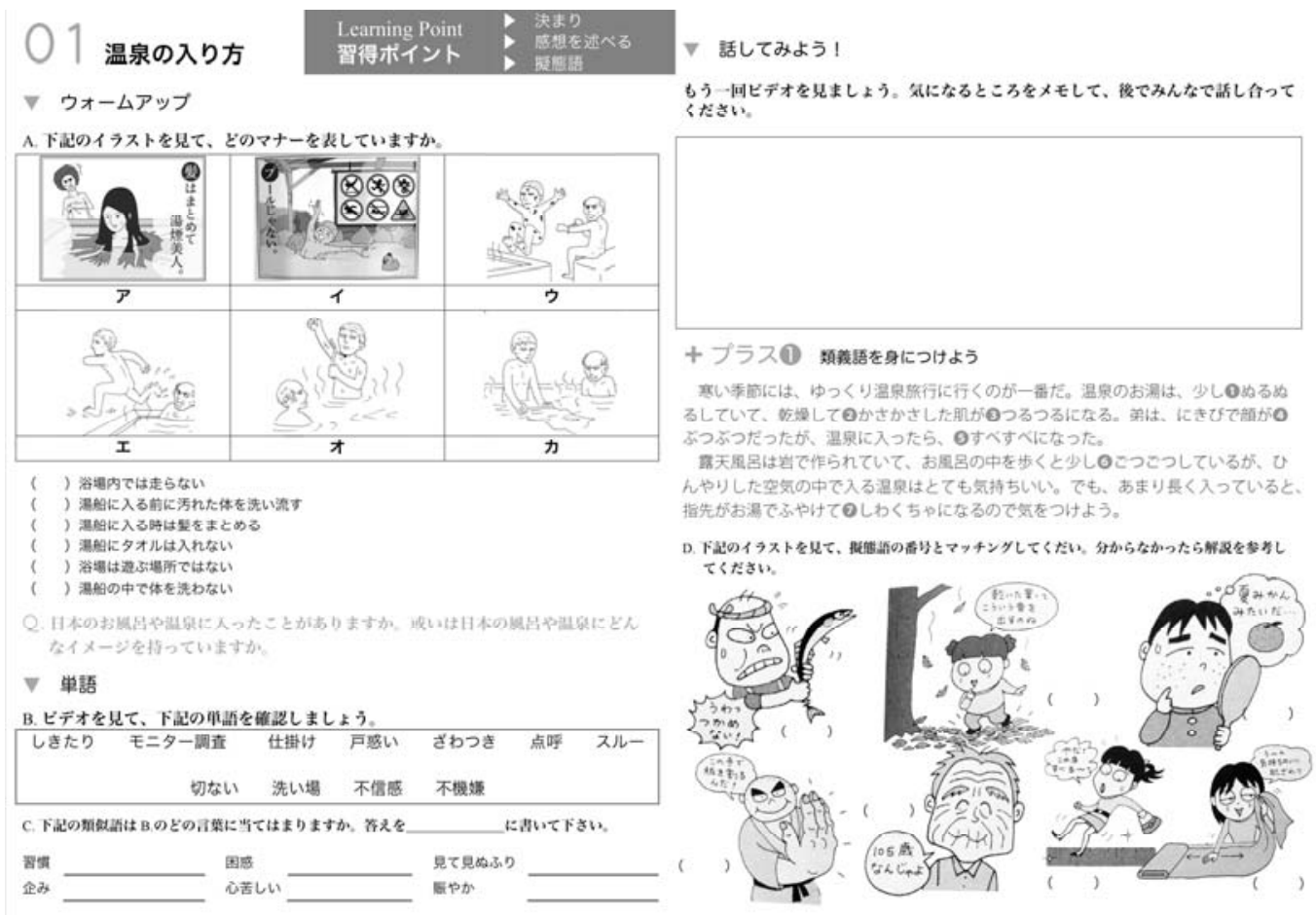


- 鲜欺

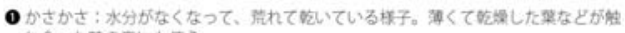

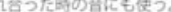

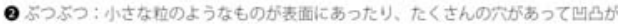

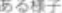

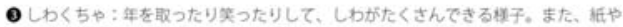

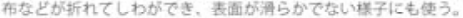

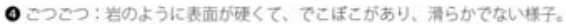

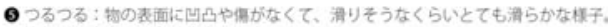

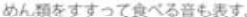

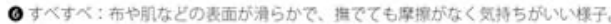

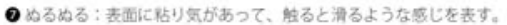

\section{○1 温泉の入り方 弆考・引用した教材 (1) ビデオ教材}

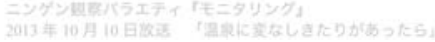

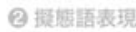

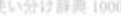

\section{○ カップルの喧唓}

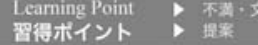

マ ウォームアップ

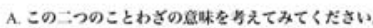

1) 船与心种に慗りなし

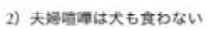

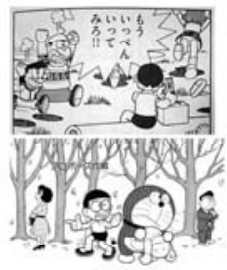

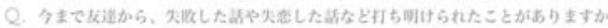

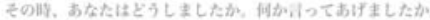

\section{จ どう思いますか}

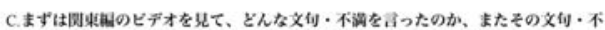

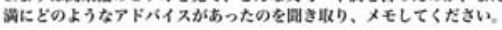

\begin{tabular}{|l|l|l|}
\hline & とんなことについて文句を言ったのか & どういうアドバイスがあった \\
\hline 1 & & \\
\hline & & \\
\hline & & \\
\hline
\end{tabular}

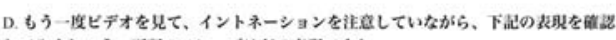
してみましょク。ト思のフレースはどのル晒てすか。

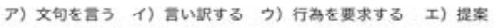

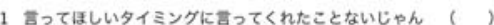

2 不安なんだち ( )

3 彼女が管ってはしいっって言ってるんだったら、吉ったカがいいと思います ( )

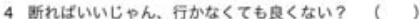

5 私だったら断るけどね! ( )

6 付合いとかもあるでしょ? ( )

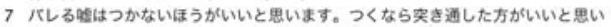

ます。（）

、 ブレインストーミング

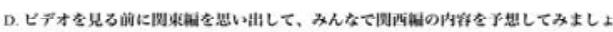
3.

話し合う

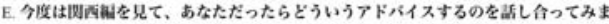
ᄂょ?.

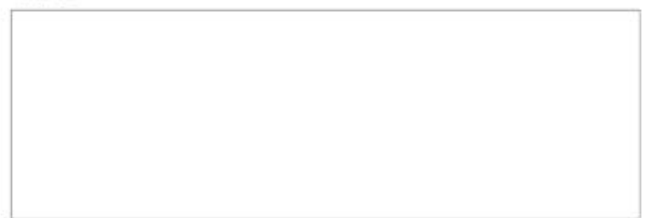

+プラス(1) 券考表現ノート

文何を暨う月

5pんと期してくれるいと、分加らないじかい

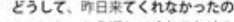

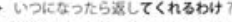

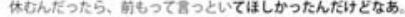

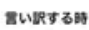

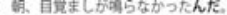

だって、日したと思っていたんだん

そのこと、㽗さんむ知ってるって黑ってたから。

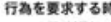

早く透していしいんたけと

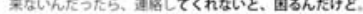

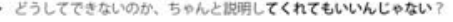

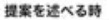

北ら上げは5时からっていうのい?

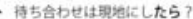

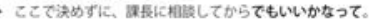

02 カッフルルの㵓睡参考・引用した教材 (1) ピテイ教材

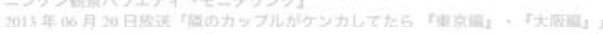

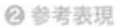

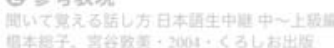




\section{付録資料 2 : 評価シートのテンプレートと授業自己評価シート}

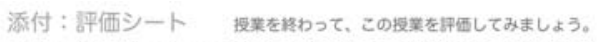

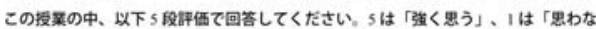
いてでる.

\begin{tabular}{|c|c|c|c|c|c|c|}
\hline & & is & & & & \\
\hline & とテォホは西白い & 5 & 4 & 3 & 2 & 1 \\
\hline & ピォの内官は清りてるるる。 & 5 & 4 & 3 & 2 & 1 \\
\hline & 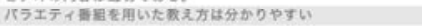 & 5 & 4 & 3 & 2 & 1 \\
\hline & 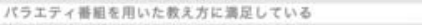 & 5 & 4 & 3 & 2 & 1 \\
\hline & 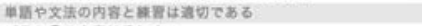 & 5 & 4 & 3 & 2 & 1 \\
\hline & フラスのめめるは役に立つ & 5 & 4 & 3 & 2 & 1 \\
\hline & 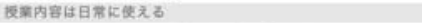 & 5 & 4 & 3 & 2 & 1 \\
\hline 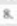 & 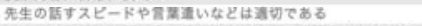 & 5 & 4 & 3 & 2 & 1 \\
\hline & 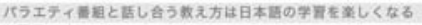 & 5 & 4 & 3 & 2 & 1 \\
\hline & 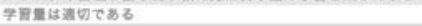 & 5 & 4 & 3 & 2 & 1 \\
\hline \multicolumn{6}{|c|}{ 、 この授亲でよかったところを教えてください。 } & \\
\hline
\end{tabular}

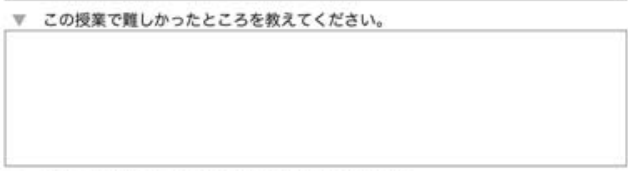

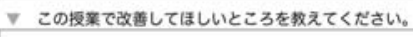

\section{授業自己評価シート}

兴基日 : 2015 年 4 月 7 日

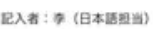

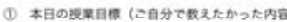

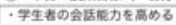

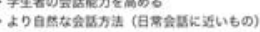

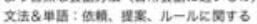

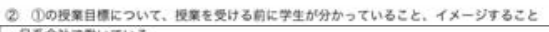

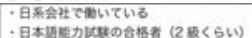

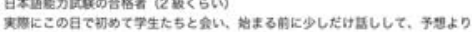

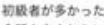

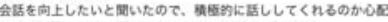

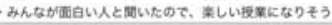

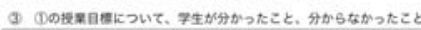

\begin{tabular}{|c|c|c|}
\hline OOKJuर & 牙DSたEE & 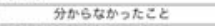 \\
\hline 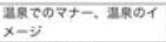 & 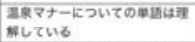 & 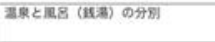 \\
\hline 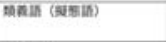 & 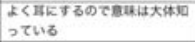 & 秋ているのて分ツするのお胡いい \\
\hline ことわむ゙ & & 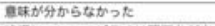 \\
\hline 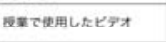 & 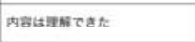 & 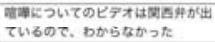 \\
\hline
\end{tabular}

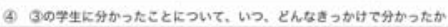

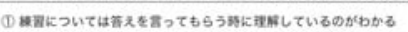

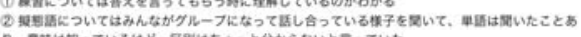

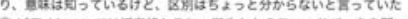

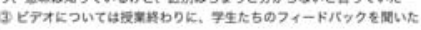

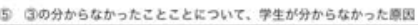

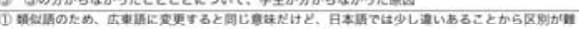

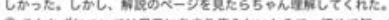

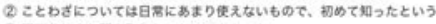

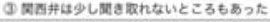

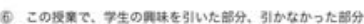

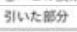

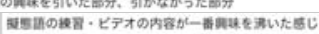

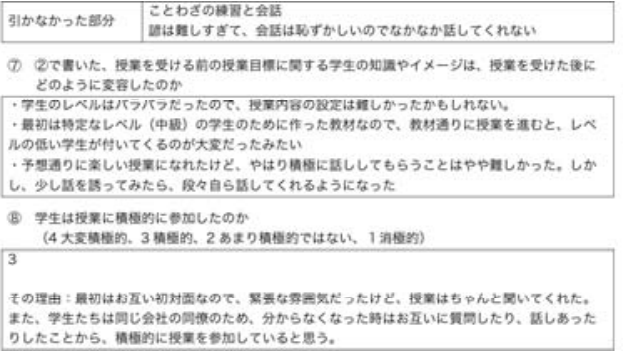

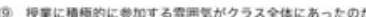

2

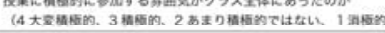

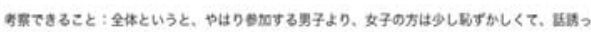

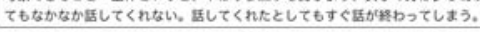

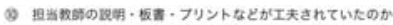

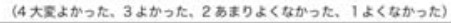

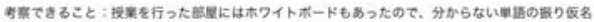

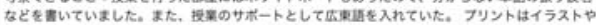

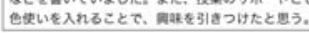

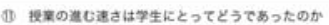$$
2
$$

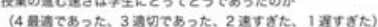

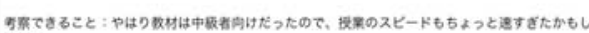
ntsw.

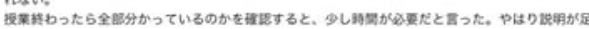

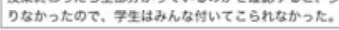

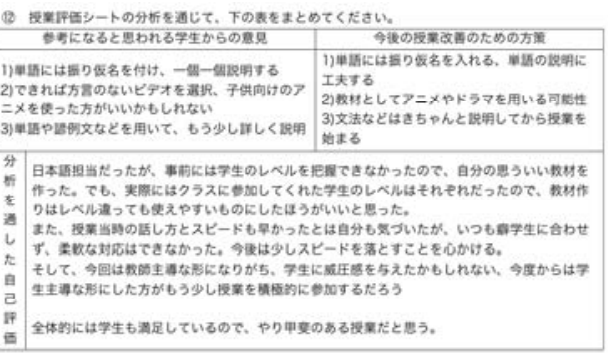

